\title{
Developing of a 3D model and analysis of the soil channel structure
}

\author{
Opracowanie modelu 3D i analiza \\ konstrukcji kanału glebowego
}

\author{
KONRAD WŁODARCZYK \\ DARIUSZ ULBRICH \\ JAROSŁAW SELECH \\ JAKUB KOWALCZYK \\ JACEK MARCINKIEWICZ \\ KRZYSZTOF PŁOTECKI*
}

DOI: https://doi.org/10.17814/mechanik.2017.7.85

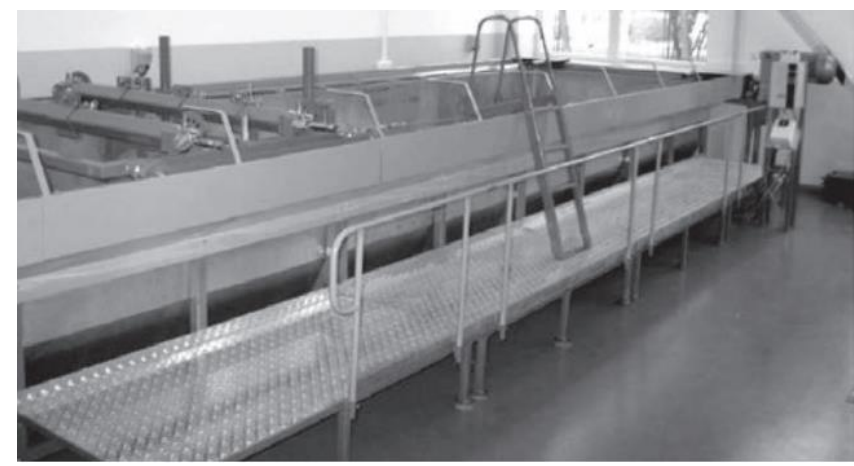

Fig. 1. Soil channel in the Department of Agricultural and Forest Machines of the SGGW in Warsaw [6]

Another example is a soil channel to study the interaction of soil tools at Urmia University in Iran (fig. 2). It has dimensions of $23 \times 2 \times 1 \mathrm{~m}(\mathrm{~L} \times \mathrm{W} \times \mathrm{H})$ and is constructed of a frame consisting of t-beam beams. In addition, the frame has rods of various cross-sections and $\mathrm{C}$-section poles as well as rails on which the trolley moves, mounted on beams of rectangular closed profile [7].
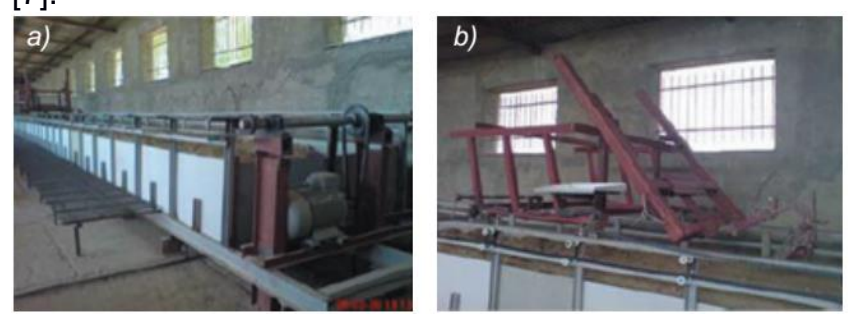

Fig. 2. Soil channel at Urmia University in Iran (a), trolley (b) [7]

At the Institute of Agricultural Engineering in Hungary, there is a soil channel for testing soil insertion tools (fig. 3 ). Its construction differs from that described earlier because it is built into the floor of the hall. This makes it possible to study the pulling force of circular chassis machines. The channel is $45 \mathrm{~m}$ long and $2 \mathrm{~m}$ wide, while the depth - due to channel construction - is not specified. The main elements of the structure are the rails on which the vehicle moves on the rubber wheels [7].

\footnotetext{
*Dr inż. Konrad Włodarczyk (konrad.wlodarczyk@put.poznan.pl), dr inż. Dariusz Ulbrich (dariusz.ulbrich@put.poznan.pl), dr inż. Jarosław Selech (jaroslaw.selech@put.poznan.pl), dr inż. Jakub Kowalczyk (jakub.kowalczyk@put.poznan.pl), mgr inż. Jacek Marcinkiewicz (jacek.marcinkiewicz@put.poznan.pl), inż. Krzysztof Płotecki (krzysztof.plotecki@student.put.poznan.pl) - Instytut Maszyn Roboczych i Pojazdów Samochodowych Politechniki

Poznańskiej
}

The design and the analysis of the soil channel elements in the ground was presented. The assumptions that should be fulfilled by the soil analysis of the model showed that the soil channel elements fulfill the strength condition and the the permissible stress. In addition, it was found that displacements of structures in the $X$-axis may cause reinforcement in the form of a beam will be attached Warsaw (fig. 1). $10 \times 2 \times 1 \mathrm{~m}(\mathrm{~L} \times \mathrm{W} \times \mathrm{H})$. The bottom plate, which presses the soil in the channel, is reinforced with $x$-shaped rods angles) reinforces the side walls and lower frame beam A set of tool wheel rollers moves along the guides mounted in the channel frame [7]. 


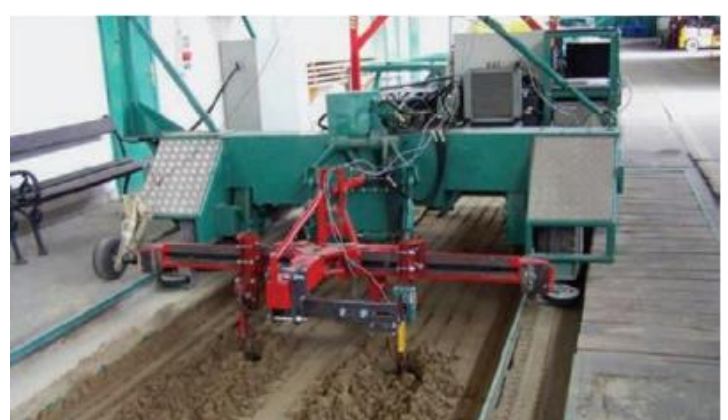

Fig. 3. Soil channel in the Institute of Agricultural Engineering in Hungary [8]

The main objective of the study presented in this paper is to develop a model of the soil channel for studying elements of working and agricultural machinery working in the soil.

\section{Structural assumptions of the soil channel}

The soil channel will be $9 \times 1.5 \times 0.9 \mathrm{~m}(\mathrm{~L} \times \mathrm{W} \times \mathrm{H})$ and effective tool length should be $8 \mathrm{~m}$. The channel frame will be constructed of square closed steel dimensions: $100 \times 100 \mathrm{~mm}$ (5 mm wall thickness). Total channel capacity will be $12.3 \mathrm{~m}^{3}$. This will allow about $20 \mathrm{t}$ of soil. It depends on the type of soil, its density and humidity. The grounding of the channel with the equipment for testing the equipment working in the ground should be about $3 \mathrm{t}$. The channel components will be made of general purpose structural steel S235JR. These will be profiles with a tensile strength of $380 \mathrm{MPa}$, resulting from the cold bending process. The construction will be welded on the sides of the walls, along the channel, rectangular profiles $(100 \times 50 \times 5 \mathrm{~mm}$, cross section of the profile) of $890 \mathrm{~mm}$ length, connected to the adjacent frame posts. They stand at $800 \mathrm{~mm}$ from the base of the canal. In addition, Rollix X46Cr13 Stainless Steel Elements are available as tool rail guides.

\section{D soil channel model}

The model was developed in Autodesk Inventor 2016. The basic elements of the soil channel are a frame structure made of square profile sections and a sheet metal cover which protects the soil from escaping from the channel (fig. 4).

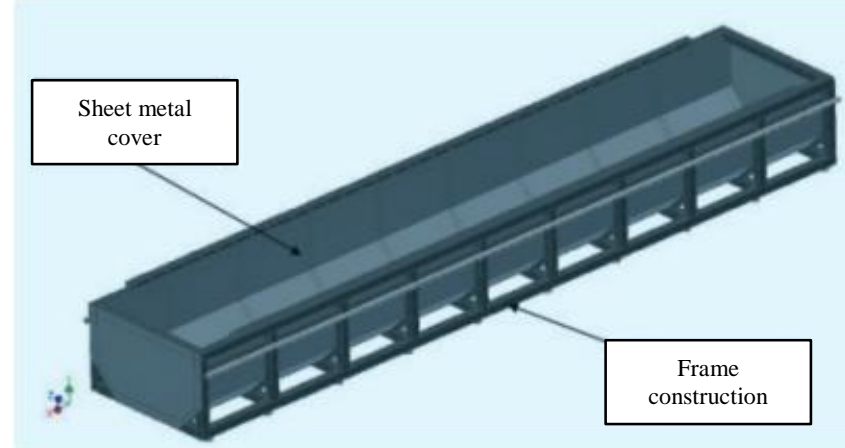

Fig. 4. Model of soil channel [7]

The soil channel was supported on 20 adjustable feet (manufactured by Vibroizolacja Poland) with a diameter of $80 \mathrm{~mm}$ (fig. 5), which were mounted on two lower beams of $9 \mathrm{~m}$ in length; The feet are spaced every 990 $\mathrm{mm}$. Each foot carries a weight of $4000 \mathrm{~kg}$.

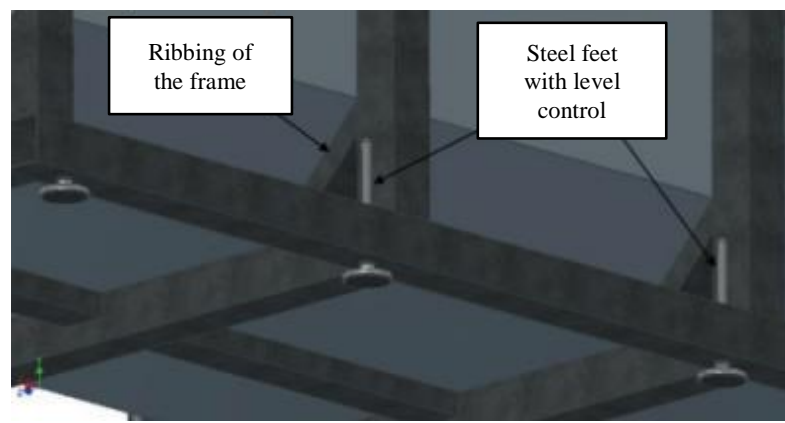

Fig. 5. Soil channel supports [7]

The side wall of the frame is made up of two main beams of $9 \mathrm{~m}$ in length, connected by 10 posts of $0.8 \mathrm{~m}$ (the cross-section of the columns is the same as the cross section of the frame beams). The main types of joints in the frame structure are face and fillet welds depending on the arrangement of the joints (fig. 6). Between the pillars were rectangular profiles of dimensions: $100 \times 50 \times 5 \mathrm{~mm}$, to which square distances were welded. Screw-shaped guides of $\varnothing 60 \mathrm{~mm}$ diameter and ground plane [7] were screwed onto them.

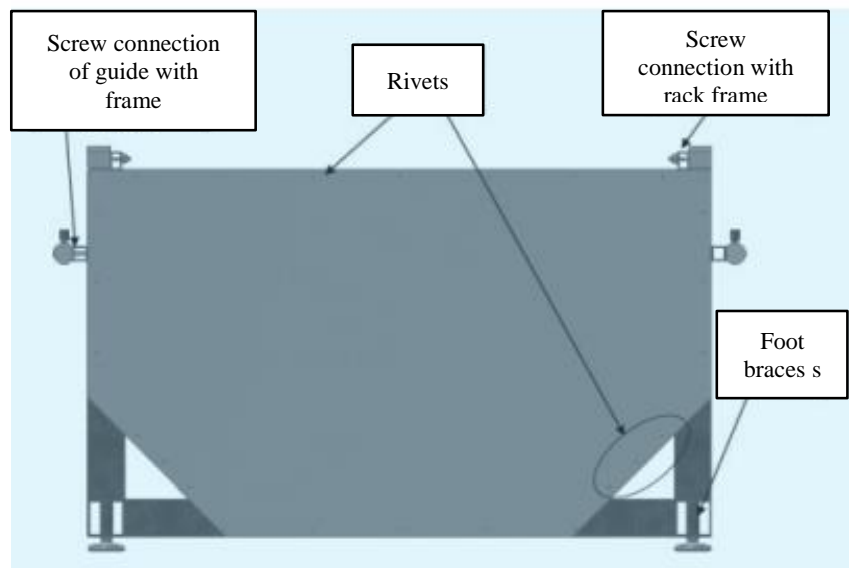

Fig. 6. View of the soil channel from the front [7]

Such a soil channel construction can be used to examine the wear of ground tools, and in the case of instrument changes, it will allow the depth of the tool to be examined in the soil [7].

\section{Analysis of MES model}

Analysis of the MES model was performed using an integrated computational package in Inventor 2016. Using the pre- and postprocessor of the engineering interpretation, the model was calculated using solid and surface elements [3-5]. For the developed and drawn model, the distribution of the stresses and displacements and the values of the structural safety factor were determined. In order to speed up the calculations, simulations were simplified [1]. During the analysis of the model removed unnecessary construction elements and holes, thus avoiding the concentration of stresses in these areas. In place of the supports, the surface of the inner frame of the steel frame was removed from which the thread was removed. In one corner support, travel in all directions and rotate around each axis. The remaining 19 supports were only moving vertically, in the $Y$ axis. The simulation included the mass of the soil and the resulting forces. Mises's reduced stresses are shown in fig. 7. Figs. 8-10 illustrate results of the displacement of the structure in three directions. 


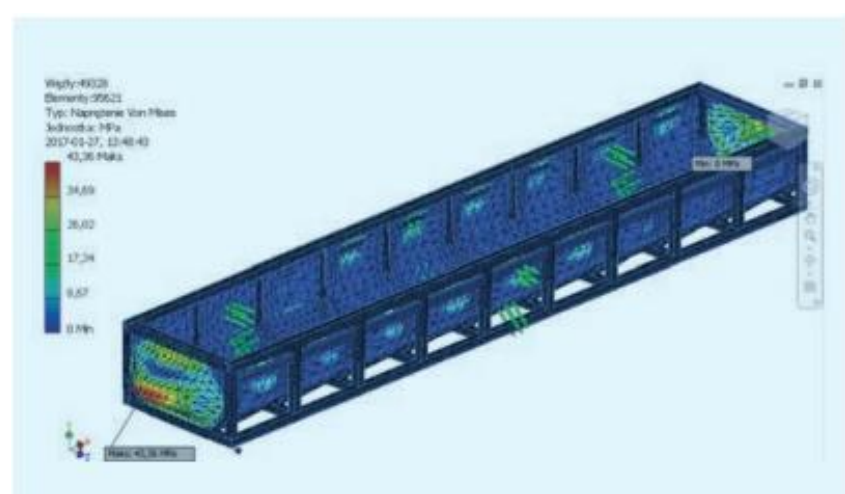

Fig. 7. Mises's stress [7]

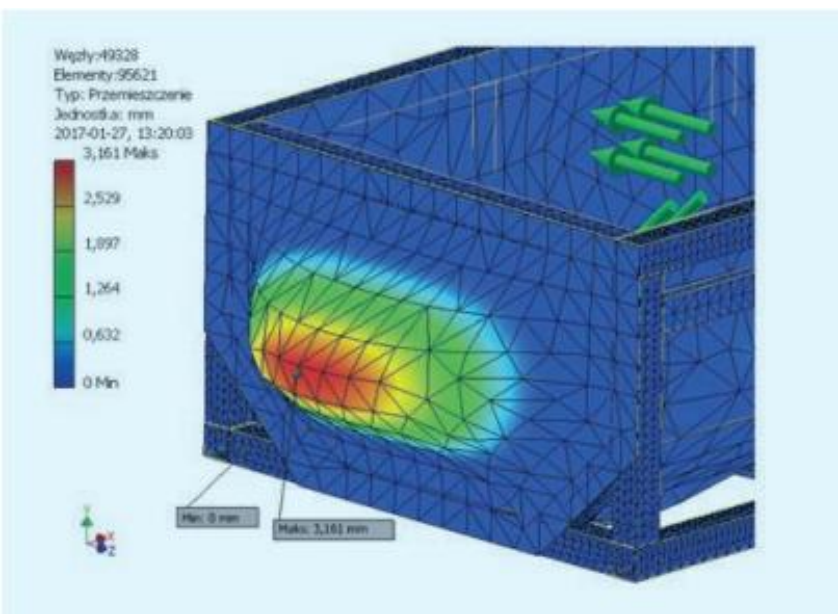

Fig. 8. Movements of structure in $X$ axis [7]

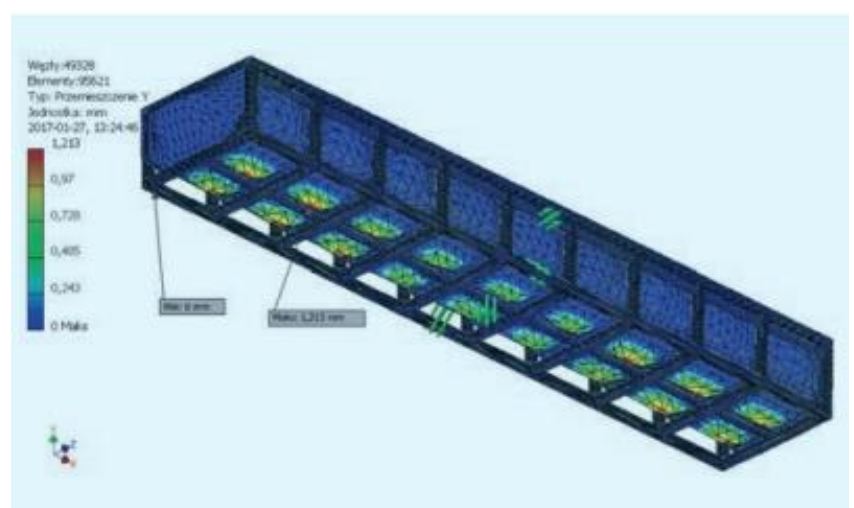

Fig. 9. Movements of structure in $Y$ axis [7]

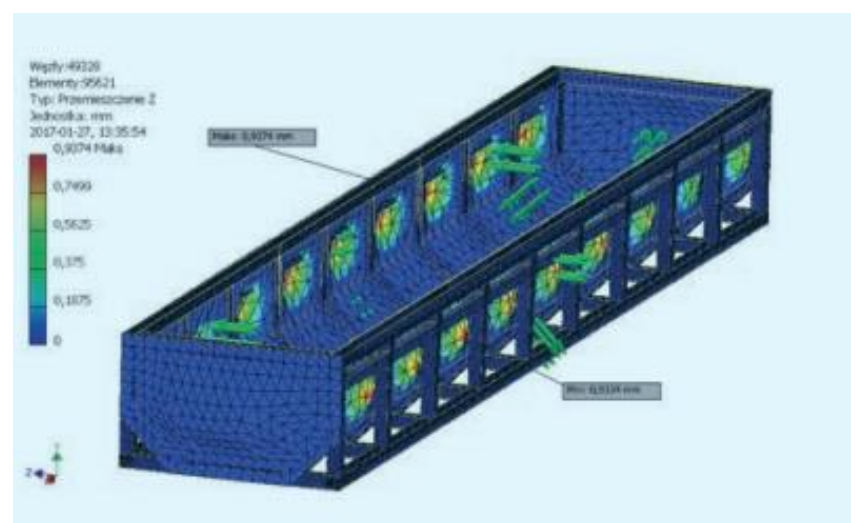

Fig. 10. Movements of structure in $Z$ axis [7]
The results of analysis of the constructed model have confirmed that the maximum stresses for the material used have not been exceeded. The permissible stresses can be $145 \mathrm{MPa}$, while the maximum stresses measured during the simulation tests were about $43 \mathrm{MPa}$. The displacement shown in the three directions refers primarily to the side plates of the channel. The maximum displacement in the direction of the $X$ axis is approx. 3.2 $\mathrm{mm}$, so an additional reinforcement in the form of a vertical beam will be added to the actual site at this site, which will reduce the stress and displacement of the channel element [7].

\section{Conclusions}

The soil channel is used to reconstruct the actual conditions prevailing during the operation of tools and work and agricultural machines, and is also used at the stage of wear testing of these components.

The maximum stresses of the developed soil channel design were about $43 \mathrm{MPa}$, thus they were significantly lower than the permissible values for the material used (145 Mpa).

The MES analysis showed a possible displacement in the $X$ axis of the soil channel elements equal to $3.2 \mathrm{~mm}$, which could lead to damage to the channel, therefore additional reinforcement will be used in the actual facility.

\section{REFERENCES}

1. Bern M., Eppstein D., Gilbert J.R.. „Provably good mesh generation”. Journal of Computer and System Sciences. 48, 3 (1994): pp. 384-409.

2. Buliński J., Klonowski J., Sergiel L. „Wykorzystanie kanału glebowego do badań zespołów roboczych narzędzi i mechanizmów jezdnych”. Inżynieria Rolnicza. 1, 119 (2010): pp. 93-98.

3. Ho-Le K. „Finite element mesh generation methods: a review and classification”. Computer-Aided Design. 20, 1 (1988): pp. 27-38.

4. Kukiełka L. Kukielka K., Kulakowska A., Patyk R., Malag L., Bohdal L., Incremental modelling and numerical solution of the contact problem between movable elastic and elastic/viscoplastic bodies and application in the technological processes". Applied Mechanics and Materials.474 (2014): pp. 159-164.

5. Marcinkiewicz J., Bieńczak A., Dembicki D., Dudziński P., Mac J.,Szczepaniak J. „Strength analysis of insulated body with use of FEM". Journal of Reserch and Application in Agriculture Engineering. 60, 1(2015): pp. 44-49.

6. Mardani A., Shahidi K., Rahmani A., Mashoofi B., Karimmaslak H. „Studies on a long soil bin for soil-tool interaction” Cercetări Agronomice în Moldova. XLIII, 2, 142 (2010): pp. 5-10.

7. Płotecki K. „Projekt ramy z układem napędowym urządzenia do badania elementów pracujących w gruncie". Praca inżynierska. Poznań:IMRiPS, 2017.

8. https://www.researchgate.net/figure/275099415_fig1_Figure2-Soil-bin-at-the-Hungarian-Institute-of-Agricultural-

Engineering-for-theDraught (2017). 